\title{
The role of motivation in the results of total productive maintenance
}

\author{
Micaela Guedes $^{\mathrm{a}}$ (D), Paulo S. Figueiredo ${ }^{\mathrm{b} *}$ (D), Camila Sousa Pereira-Guizzo ${ }^{\mathrm{a}}$ (D), Elisabeth Loiola ${ }^{\mathrm{b}}$ \\ ${ }^{a}$ Centro Universitário Senai Cimatec, Salvador, BA, Brasil \\ bUniversidade Federal da Bahia, Salvador, BA, Brasil \\ *paulo_s_figueiredo@hotmail.com
}

\begin{abstract}
Paper aims: The aim is to analyze the role of motivation of work teams in production lines in the operational results obtained with the implementation of a Total Productive Maintenance (TPM) program in a single company.

Originality: The areas of industrial production and maintenance require that human factors influencing performance be continuously investigated and cannot focus exclusively on the reliability of equipment and systems. Studies that contemplate these factors are relatively scarce but of great value for companies and society.
\end{abstract}

Research method: This is an exploratory case study that used a measurement of motivation with two teams of employees who participated in the implementation of TPM, comparing it to measures of operational performance. Unstructured interviews and nonparticipant observation were also used for data collection.

Main findings: The level of motivation of the team was positively associated with a change in operational performance, and the implementation of TPM had a positive impact on performance.

Implications for theory and practice: This study contributes to the behavioral operations management literature by showing empirical evidence that operational results may depend on motivated workers during TPM implementation. Managers must pay attention to the factors that determine the motivation of work teams when implementing improvement programs.

Keywords

Total productive maintenance. Work motivation. Operational performance. Behavioral operations management.

How to cite this article: Guedes, M., Figueiredo, P. S., Pereira-Guizzo, C. S., Loiola, E. (2021). The role of motivation in the results of total productive maintenance. Production, 31, e20200057. https://doi.org/10.1590/0103-6513.20200057

Received: June 10, 2020; Accepted: Nov. 03, 2020.

\section{Introduction}

Research results relating motivation and work have encouraged organizations to efficiently value its workers to maintain a prominent place in today's highly competitive market (Macintosh, \& Doherty, 2010; Stringer et al., 2011). Even in a training context, motivation can influence the willingness of an employee to participate in a program and put in practice the best way to apply what has been learned (Maurer, \& Tarulli, 1994; Noe, \& Wilk, 1993).

Although this is a relatively well investigated topic, the study of the factors that motivate workers and, consequently, organizations to achieve good performance still demands the accumulation of observations obtained in different countries, whose workers are governed by specific institutional norms linked to work and are immersed in different cultures, as well as in companies of varied size, markets, work organization, skills and workforce skills (Di Cesare, \& Sadri, 2003).

Another factor highly interdependent with the performance of the industrial company is maintenance, defined by Pintelon \& Van Puyvelde (2006) as a combination of all the technical and administrative activities necessary to keep equipment, installations and other assets in the desired operating condition or restore them 
to this condition. Meselhy et al. (2010) state that maintenance policies and programs in production systems should be designed to ensure reliability, availability, efficiency and capacity. There is a consensus among the authors (Lee Cooke, 2000; Madu, 2000) that the maintenance of equipment and the reliability of the system affect the ability of organizations to provide high-quality services to their customers.

The alignment of the goals of the maintenance function with production and corporate goals guides the maintenance efforts towards achieving the performance and continuous improvement of the production equipment and, consequently, of the production system (Muchiri et al., 2011). Total Productive Maintenance (TPM) is an important tool in this context that has such objective. lt is a system developed in Japan to eliminate losses, reduce downtime, ensure quality and reduce costs in companies, in a continuous process (Wienclaw, 2018). Even though there is vast evidence that TPM can improve operational performance (e.g. Hooi \& Leong, 2017; Modgil \& Sharma, 2016; Habidin et al., 2018; Wickramasinghe \& Perera, 2016), studies focused on the impact of the human factor on the results of the implementation and use of TPM are scarce. Many studies mention the importance of the motivation of workers for the success of TPM implementation, however, such studies are frequently prescriptive in nature and not based on quantitative evidence. The studies by Jain et al. (2018), Kareem \& Amin (2017), Bamber et al. (1999), Attri et al. (2013), and Sharma et al. (2016) stand out by presenting empirical and quantitative evidence of the importance of motivation in the TPM context. This study aims to contribute to this specific body of literature. However, most of these quantitative studies focus on the motivation of workers during the day-to-day operations of companies using TPM, and not on the implementation process itself. The focus on the role of motivation in the implementation process constitutes a specific contribution of this research.

The main objective of this research is, therefore, to study the role of the motivation factor of production line teams of an industrial company in the operational performance obtained with the implementation of TPM. The company studied implemented a TPM program with the main purpose of reducing costs and downtime and ensuring the quality standards required by its consumer market. Thus, the research question is as follows: In the studied company, to what extent can the motivation factor influence operational performance after the implementation of a TPM system?

This study is structured as follows: First, a literature review focusing on TPM implementation and the role of motivation of teams is presented, followed by a list of the research hypotheses and by the proposed conceptual model. Next, the methodology is discussed, followed by a section focused on the results and discussion, and finally the concluding remarks are presented in the last section.

\section{Literature review}

The literature review discusses the Total Productive Maintenance system and workforce motivation, focusing on TPM implementation, on the role of motivation in the performance of workers, and on the conceptual model and hypotheses that are proposed in this study.

\subsection{Implementation of TPM}

Formal continuous improvement programs appeared for the first time in Japan in the second half of the twentieth century (Michela et al., 1996). In the 21 st century, organizational innovation and learning techniques have been adopted as part of the competitive strategy, supported by continuous improvement programs based on the Japanese Kaizen approach. Many of these techniques aim to make predictions about the most likely moments in which a failure may occur and thus avoid it through a focused intervention (Sellitto et al., 2002). The organization and operationalization of companies for this competitive strategy came with programs, such as the TPM, which focused on agility and production flexibility (Boer \& Gertsen, 2003; Nakajima, 1998; Venkatesh, 2003).

Among the various aspects of the TPM program, one of the main pillars is Autonomous Maintenance, which mainly focuses on eliminating the losses generated by the misuse of equipment and human resources, eliminating nonconformances and developing, through the operators, small and continuous local improvements (Nakajima, 1998; Petter et al. 2011; Venkatesh, 2003). Autonomous maintenance can be understood as a shift from "1 manufacture, you repair" to "1 myself take care of my equipment" (Petter et al., 2011).

To maximize factory efficiency, all that reduces efficiency, i.e., losses, must be eliminated. The central idea of the programs (and of what was implemented in the studied company) is the complete elimination of the six big losses related to the equipment: breakdowns, machine setup and adjustments, idling times, reduced speed, process defects (scrap and rework) and reduced yield at the beginning of the shift (Nakazato, 1999). It is evident 
that beyond the competencies and skills of workers, the engagement and motivation of the workforce with the TPM system are strategic for achieving the desired results.

According to the TPM approach, the most profitable factories would not necessarily be the ones with the newest equipment if managed according to the TPM strategy (Imai, 2000). Thus, the older companies, if well managed in terms of TPM, could eventually provide greater value to shareholders than the new ones, since they would no longer pay the interest and amortization charges. Thus, many reductions in processing costs would be obtained by innovations that seek to exploit as much as possible the use of existing assets (Takahashi \& Osada, 1993).

The implementation of TPM has resulted in increases in efficiency in the use of installed capacity in Japanese industrial companies that have fluctuated between 60 and 90\% (Tondato, 2004). Ljungberg (1998) presents cases in which, due to structured TPM implementation programs, there was a significant reduction in scrap and rework, at the same time as there was a reduction in the number of machine breaks and unexpected production interruption. One result of this increase in efficiency is the reduction in the need for new capital investments in the plant, as it is possible to produce more with the same amount of assets (Dogra et al., 2011).

Hooi \& Leong (2017), based on a sample of Malaysian manufacturing organisations state that TPM implementation initiatives have a positive effect on manufacturing performance, but not on top management leadership and maintenance organization. The authors suggest that top management commitment and roles are essential in the initial stages, in order to devise the master plan and initiate the implementation of the entire program. Modgil \& Sharma (2016), based on a study with a large sample of Indian pharmaceutical companies, conclude that TPM practices have a positive impact on operational performance at the plant-level. The authors also propose that when TPM and Total Quality Management (TQM) practices are combined, then TPM exerts an even higher influence on operational performance. Habidin et al. (2018) conclude that in the Malaysian automotive industry, there is evidence that TPM improves innovation performance, and that the impact of TPM on innovation performance increases with the mediating effect of kaizen events. Wickramasinghe \& Perera (2016) studied the benefits of TPM practices on textile and apparel manufacturing firms, and concluded that these practices improved cost effectiveness, product quality, on-time delivery and volume flexibility.

In summary, there is evidence that the successful implementation of TPM has a positive and significant relationship with cost reduction, increased quality and meeting delivery times (Dogra et al., 2011; ljungberg, 1998; Mckone et al., 2001; Tondato, 2004) and that these organizational performance indicators may depend on workers' motivation (Sekhar et al., 2013).

\subsection{The role of motivation in the performance of workers}

Studies in the field of psychology on work meaning began to emerge in the 1980s (Borges et al., 2008) and even before that (Campbell et al., 1970). Adjacent to the broad field of work meaning, worker motivation is a subject of crucial importance for the success of organizations and societies and for the well-being of individuals (Herzberg, 2008). Vroom's Expectancy Theory (Vroom, 1964) has provided the basis for several studies on work motivation, either directly or indirectly, based on five basic concepts (Work Outcomes, Valence, Expectancy, Instrumentality and Motivational Force). This last concept is a central variable to the present study and refers to the amount of effort or pressure within the person to be motivated. According to Vroom (1964), motivational force is obtained by the multiplication of valences, instrumentalities and expectancies.

For Frohman (1996), motivated individuals exert greater effort to perform a task than people who are not motivated. Silva (2009) states that when measuring the effectiveness of teams, it is essential to consider the criteria related to the satisfaction and motivation of the subject, in addition to the productivity indices, considering that, according to Erez (1997), dissatisfied employees are unwilling to devote knowledge, efforts and personal skills at work. Motivation affects the skills that individuals develop, their jobs and careers, and the way in which they allocate their resources (for example, attention, effort, time and human and social capital), which, in turn, affect the direction, intensity and persistence of work activities (Kanfer et al., 2017).

According to Jahn (1996), workers feel more motivated when they belong to a team where they are free to make suggestions because the feeling of belonging to a group is one of the basic needs of the human being. Nesan \& Holt (1999) observed that teams are especially motivated when they are given the opportunity to self-manage. Both researchers focus their research on the form of work organization, concluding that the degree of autonomy in work management by the team favors worker motivation. Other factors such as work conditions, compensation system and organizational investments in the development of a sense of belonging and in organizational feedback for a job well done also influence the motivation of workers (DiPietro et al., 2014). 
Several studies have related employee motivation to operational performance measured in different ways (e.g., time, quality, cost, flexibility). For example, Guo et al. (2017) studied how the motivation related to voluntary information sharing between functions can affect operational performance. Guclu \& Guney (2017), as well as Khan \& Baloch (2017), studied how motivational techniques used by managers can increase the productivity of employees on the shop floor. Bennett \& Levinthal (2017) established a positive link between workforce motivation and firm growth. Finally, Cordero et al. (2005) concluded that the traditional dimensions of performance, especially productivity, quality and lead-time, are positively influenced by incentive plans aimed at increasing motivation; however, this type of traditional incentive is not effective in promoting creative work in the innovation process in manufacturing plants.

A few studies focused on the importance and impact of employee motivation on TPM results. Jain et al. (2018) show evidence that employee motivation, along with other human-related factors is a key enabler for TPM implementation. Kareem \& Amin (2017) studied the role of psychological and ethical factors in the implementation of TPM and concluded that employee motivation and morale is an important factor to enable success. Bamber et al. (1999) studied TPM implementation in UK manufacturing organizations and concluded that workforce and management motivation are key success factors. Attri et al. (2013) concluded that it is important that all employees participating in TPM activities be motivated to do so, since motivation may change employee behavior from negative to positive. Sharma et al. (2016), based on a sample of Indian manufacturing companies, suggest that the variable that is most difficult to control in TPM implementation, despite its importance, is the human element, which includes employee motivation.

The challenge of measuring motivation based on Vroom's Expectancy Theory (Vroom, 1964) was taken up by Borges \& Alves Filho (2001), who developed, for that purpose, the Work Motivation and Meaning Inventory (WMMI). This instrument proved to be robust to measure motivation in several studies (Alves et al., 2016; Alves Filho \& Borges, 2014; Varella, 2006; Rufatto et al., 2017; Silva \& Barros, 2018). For this reason, this is the instrument used to measure motivation in this study, instead of other seminal models that have not been validated in our language (Gagné et al., 2010).

Based on the Expectancy Theory and using the WMMl, developed by Borges \& Alves Filho (2001), Abreu (2011) investigated the role of work motivation in an automotive industry and concluded that the motivation factor contributes to better performance of the employees involved, improving the achievement of results and increasing productivity in a highly competitive sector.

\subsection{Hypotheses and conceptual model}

Based on the literature review, two hypotheses are defined that underlie this study, which refer to the case of the researched company:

$\mathrm{H}$ 1: "A higher level of motivation of the team is associated with a positive change in operational performance after the implementation of a TPM program."

H2: "The operational performance of production lines is positively impacted after the implementation of a TPM program."

Figure 1 shows the proposed conceptual framework that presents both hypotheses graphically. lt represents the relationship between motivation and degree of success with the implementation of a TPM program, in addition to the impact of the TPM system on operational performance, measured in its basic dimensions of cost, quality and time, which constitute the "iron triangle" (Papke-Shields et al., 2010; Taherdoost, \& Keshavarzsaleh, 2016). These dimensions were operationalized in the study by proxies of efficiency, downtime, product cost, and waste.

\section{Methods}

This is an exploratory case study, where performance data from two production lines from a single company were collected by applying the WMMI (Borges \& Alves Filho, 2001) to 18 employees of the work team of these lines. In addition, unstructured in-person interviews were conducted during the implementation of TPM with all 18 employees who responded to the questionnaires, and nonparticipant observation was carried out during the entire implementation period.

In the previous section, many studies that focus on understanding how organizational and cultural factors influence motivation were mentioned, but it is important to point out that it is out of the scope of this study to explore these issues, since the main research objective is to establish a link between motivation in TPM 


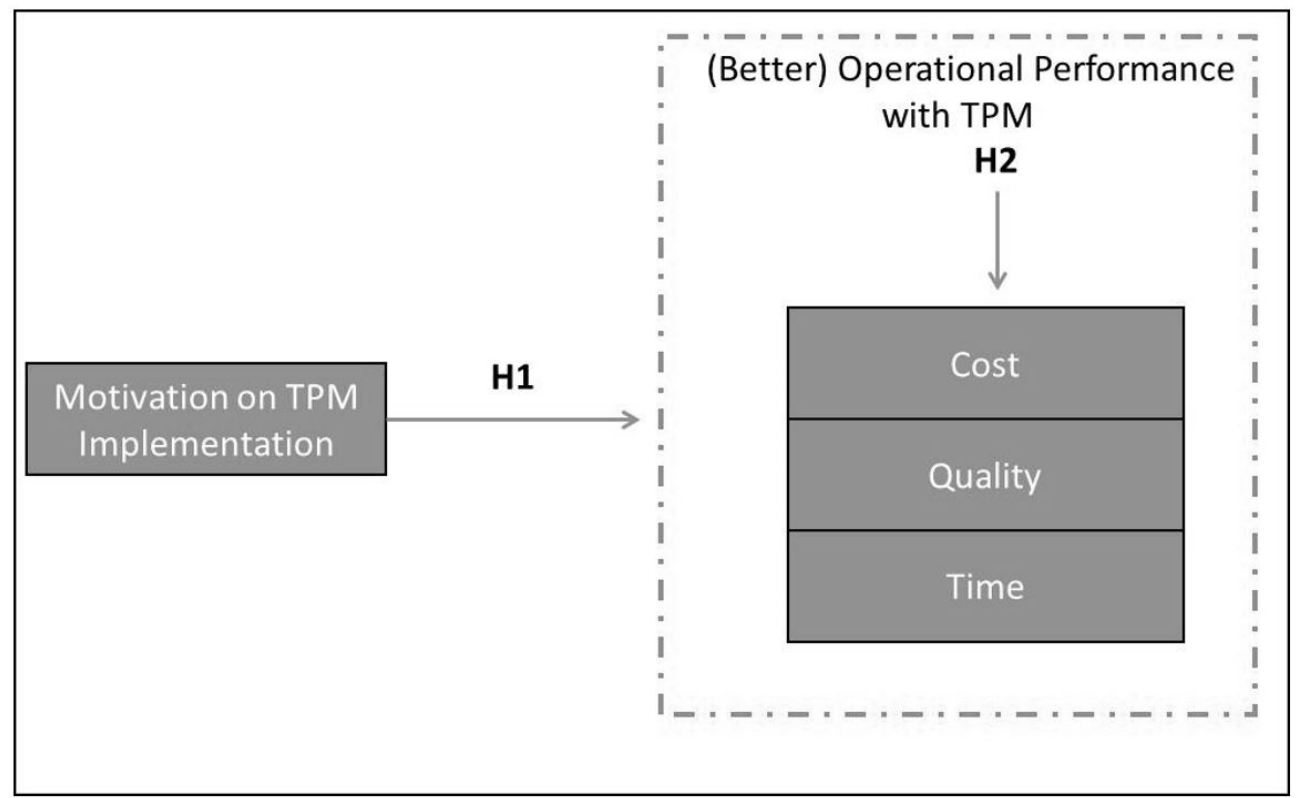

Figure 1. Conceptual model of the relationship between motivation, TPM and operational performance. Source: The authors.

implementation and operational results. A study focusing specifically on the organizational and cultural factors is beyond the proposed objectives and was not carried out, even though reasons for the differences found in the motivational factor of the teams were analyzed. Since this study focuses on a single company, it is reasonable to assume that cultural factors and organizational factors are shared by members of both teams, therefore not influencing the results presented here. The same applies to the differences in skills, since both groups received the same kind of training, and the groups are similar in age and years of work experience, however with some degree of differences in terms of technical skills.

\subsection{Research site}

The company in which the study was conducted is an American multinational company that operates in 35 countries and markets its products in more than 150 countries. The study was conducted in a factory located in the state of Bahia, with a unit of approximately 600 direct employees, where they manufacture feminine care, child care and personal hygiene products.

The study was conducted in two production lines, herein called line 1 and line 2 . The work team of each line is fixed, i.e., employees do not change lines. Each production line is operated by nine employees distributed in three work shifts, and each shift has three operators per line, in addition to one relief operator per line, totaling 12 employees per line. The first shift occurs in the morning (from 06:00 to 14:00), the second in the afternoon (from 14:00 to 22:00) and the third in the evening (from 10:00 pm to 06:00 am the next day), thus operating 24 hours per day. There was no line turnover during the study period.

Production lines 1 and 2 are lines with similar technology and the same production capacity, and differ only in the type of product they produce. Because it is the same company, the same category of products, the same support team and the same leadership, training and development factors are the same for the two production lines. In addition, factors such as production technology and workforce remained practically unchanged in the period, which reduces the chance of other factors having influenced the difference in the gains obtained with the implementation of the TPM in the two lines, thus providing greater internal validity to the study.

\subsection{Systematics of data collection and processing}

This section is divided in two parts, namely data collection and data analysis, and focuses on explaining the procedures that were used for collecting qualitative and quantitative data, and explaining how these data were analyzed for the purposes of the study. 


\subsubsection{Data collection}

Data regarding the product cost, waste, downtime and efficiency in the six-month period before the implementation of the TPM and six months after implementation in two production lines were collected. These operational performance variables were collected in the company's system and in management reports through software that measures these performance indices. It is important to note that in the period studied, the cost of raw materials remained stable and practically unchanged.

The WMMI was administered as recommended by the WMMl instrument's author (Borges \& Alves Filho, 2001), with the use of a closed questionnaire and structured interviews, exclusively containing questions from the WMMI, after the implementation of TPM in 18 employees of the two production lines, with nine employees from each of the lines and different work shifts, representing 75\% of the total number of employees in each line. Data were collected with practically all members of the two production lines, with only one person from each team per shift not responding to the survey. The technical training of all of the employees who contributed to this study consisted of courses, mostly on mechanical and electrical maintenance. In addition, all employees had more than four years of experience in the company and are aged between 25 and 28 years.

To obtain explanations for differences in the motivational indices of the teams, during the implementation, two meetings followed by unstructured interviews were conducted with the operational team and with all the operators of the two lines. These interviews were conducted by a graduate student in those two occasions only, and the choice of non-structured interviews was a deliberate decision, aiming to induce more spontaneous responses from the workers about their motivation during the TPM implementation process and the reasons behind their assessments. Nonparticipant observation was carried out by the student during the entire implementation period, usually every ten to fourteen days. All the operators of the two lines participated in meetings and interviews, however only the most significant responses are presented here, since there was consensus and redundancy about most of the issues among workers of each team. The data were collected and the answers were analyzed and categorized qualitatively according to content. The data analysis was initially performed by the graduate student and later on, the data was reassessed by two PhD-level researchers, in an attempt to reduce bias or distortion due to the interviewer's experience and subjective interpretation. No distortions were identified.

Therefore, a mixed methodological approach was used, integrating quantitative data with data from interviews involving workers experiencing the TPM project. The analysis was carried out in different moments of the project implementation. Such an approach aimed to increase the internal validity of the study, in the same way as found in the work of Gaiardelli et al. (2019), who addressed a very similar problem using the same methodological approach. Moreover, this study can be helpful to widen the analysis found in the literature on the role of motivation in workers' performance. Indeed, Gaiardelli et al. (2019) suggested that workers' motivation depends both on the physical conditions of work environments (workplace safety, spatial arrangements, cleanliness, environmental properties, and comfort) as well as on job characteristics (skill variety, task significance, feedback and autonomy). The qualitative analysis presented here, however brief and simple, aimed to take some of these issues into account.

\subsubsection{Data analysis}

The waste is the percentage related to the total number of products discarded due to manufacturing defects relative to the total number of products produced; both values refer to the equivalent month. The unit cost of the product is calculated by adding the fixed and variable costs for manufacturing the products in a given month over the total monthly volume of products. In regard to efficiency, the KPI used in the studied company is the OEE - Overall Equipment Effectiveness, which is one of the main indicators monitored in the company because it measures the effectiveness of the equipment; this parameter is also measured in percentage. OEE measures how well a production line works relative to its projected capacity during the time it is scheduled to run. OEE takes into account efficiency in three dimensions: availability, performance and quality. The three components are multiplied to calculate the OEE index (Hansen, 2005).

Regarding the measurement of the motivation variable, the WMMl, developed by Borges \& Alves Filho (2001), was used. It is an instrument with reliable psychometric properties for the study of motivation (Borges \& Alves Filho, 2003; Borges et al., 2008). The WMMl aims to broaden the understanding of the relationships of professionals with their work, and consists of four components (value attributes, descriptive attributes, expectations and instrumentality), with specific items (questions) and factor structure in each component. Each item has an assigned weight that, once placed in its factorial structure, allows calculation of the constructs to be measured. In this study, questionnaires for expectation and instrumentality, which are necessary to calculate 
the motivational force (Borges et al., 2008), were specifically used. Instrumentality consists of the degree of perceived relationship between execution of work (the total performance) and achievement of results. Expectancy consists of the perception of how much effort leads to expected results. It is the degree to which the individual believes that a specific outcome is likely. It is a subjective probability that can be described according to its intensity (Borges \& Alves Filho, 2001).

In the WMMI, motivational force (MF) is the amount of effort or pressure a person applies to motivate him- or herself. MF is a measure of the "motivation" construct.

The motivational force is obtained from the product of the sums of scores of the expectancy and instrumentality factors (the sum of expectancies 1, 3, 4 and 5 multiplied by the sum of instrumentalities 1, 2, 4 and 5), subtracted by the product of the scores of the expectancy and instrumentality factors relating to undesirable or unattractive work results, for which, hypothetically, negative valence is attributed; these two factors are related to wear and dehumanization (expectancy 2 and instrumentality 3, respectively). The calculation is shown in Equation 1 (Borges \& Alves Filho, 2001).

$$
M F=\left[\Sigma(F e 1, F e 3, F e 4, F e 5) * \sum(F i 1, F i 2, F i 4, F i 5)\right]-(F e 2 * F i 3)
$$

Equation 1 can be translated as follows: Fe2 and Fi3 measure the negative valence; Fe1, Fe3, Fe4, and Fe5 measure the expectancy; and Fi1, Fi2, Fi4, and Fi5 measure the instrumentality.

To test one of the main hypotheses of this study, the mean motivational indices of each team (obtained through an average of motivational force results of each team member) were compared with the average operational performance considering a period of six months after the implementation of the TPM. The nonparametric MannWhitney test was used to determine whether there were significant gains in operational performance in the period after the implementation of TPM relative to the period prior to it and to compare the motivation indices in the two lines. It was assumed, however, that the cost values constitute a series of values not independent in time; therefore, in this case, the Wilcoxon test was used (Wilcoxon, 1945).

Regarding the data analysis of the unstructured interviews, these interviews were recorded, totaling 4 hours of audio and were subsequently transcribed and analyzed. . The responses to the interviews with the supervisors were analyzed qualitatively according to the content, using as a criterion the grouping by thematic categories.

\section{Results}

In this section, the results of the study and the discussion are presented, focusing on testing the two hypotheses that were previously mentioned.

\subsection{Motivational Force (WMMI)}

Table 1 shows the results of the motivational force factors, following the procedure described in the literature, which represent the amount of effort that the employee makes to motivate him/herself. This factor can range between 0 and 256. According to Table 1, the most motivated operator is in line 1 with a factor of 226 and the least motivated operator is in line 2 with a factor of 83 . The motivation factor of the lines is also shown in Table 1 and is obtained by averaging the factors of the employees. Line 1 had a factor of 202 and line 2, a factor of 105, almost half of the value of line 1. The Mann-Whitney test between means shows that the difference between them is statistically significant ( $p$-value of 0.000041$)$. It is concluded, therefore, that the Line 2 team is less motivated than the line 1 team. In addition, the results of the factors of line 2 respondents show greater dispersion (coefficient of variation greater than that of Line 1). This means that besides being less motivated on average, there was more variation in the responses of members of team 2, indicating different perceptions and perhaps disagreement.

\subsection{Operational performance}

To compare the postimplementation effectiveness, data were collected on the product cost, waste, efficiency and downtime in the period of six months before the implementation of the TPM and six months after implementation, in each line, with the objective of measuring whether there were significant improvements in these operational performance indicators.

Table 2 shows data on operational performance for each month in the two production lines. 


\begin{tabular}{|c|c|c|c|c|c|c|}
\hline \multirow[b]{2}{*}{ Lines } & \multirow[b]{2}{*}{ Names } & \multicolumn{5}{|c|}{$\mathrm{MF}$} \\
\hline & & $\begin{array}{c}\text { Motivational } \\
\text { Force (0 to 256) }\end{array}$ & Mean MF & $\begin{array}{l}\text { Standard } \\
\text { Deviation }\end{array}$ & $\begin{array}{l}\text { Coefficient of } \\
\text { variation }(\%)\end{array}$ & P-Value \\
\hline \multirow{9}{*}{ LINE 1} & Operator 1 & 201 & & & & \multirow{18}{*}{0.000041} \\
\hline & Operator 2 & 190 & & & & \\
\hline & Operator 3 & 203 & & & & \\
\hline & Operator 4 & 199 & & & & \\
\hline & Operator 5 & 198 & 202 & 12 & 5.94 & \\
\hline & Operator 6 & 212 & & & & \\
\hline & Operator 7 & 183 & & & & \\
\hline & Operator 8 & 226 & & & & \\
\hline & Operator 9 & 206 & & & & \\
\hline \multirow{9}{*}{ LINE 2} & Operator 10 & 121 & \multirow{9}{*}{105} & \multirow{9}{*}{16} & \multirow{9}{*}{15.23} & \\
\hline & Operator 11 & 83 & & & & \\
\hline & Operator 12 & 93 & & & & \\
\hline & Operator 13 & 131 & & & & \\
\hline & Operator 14 & 124 & & & & \\
\hline & Operator 15 & 101 & & & & \\
\hline & Operator 16 & 100 & & & & \\
\hline & Operator 17 & 99 & & & & \\
\hline & Operator 18 & 92 & & & & \\
\hline
\end{tabular}

Source: Authors.

The product cost is calculated dividing the total cost (sum of the fixed and variable costs of the month) by the total volume of good products produced. The two lines produce products of the same family and type. The only difference is the existence of limitations in the package size of the products that, in some cases, are restricted per line.

The Wilcoxon test was performed. Statistically, there is no significant difference between between the previous and the subsequent values of cost in both lines because the P-value is above 0.05 , the chosen level for determining significance. However, numerically, there was a $13.18 \%$ reduction in the mean product cost in Line 1 compared to a reduction of 3\% in the mean cost in line 2.

Table 2 also presents the percentage of waste of each month for each line, before and after the implementation of the TPM, which refers to the percentage of products thrown away for not meeting their specifications. In Line 1 , there was a reduction of almost $32 \%$ in the mean percentage after implementation compared to the previous mean percentage. In Line 2 there was a reduction of only $8 \%$ in the value. Statistical analysis shows that there was a significant change only in the waste of line 1 .

Data related to the percentage efficiency of each equipment per month before and after implementation of the TPM are also presented. In Line 1, there was an increase of approximately $12 \%$ in the mean percentage after implementation compared to the previous mean percentage, while line 2 increased only almost 3\% in value. Through statistical analysis, it was confirmed that there was a significant change in efficiency only in line 1.

As already mentioned, one of the ways to measure the gain after implementation of the TPM is to measure machine availability, a factor that is also impacted by the machine downtime. Table 2 shows the comparison of the downtime hours before and after the implementation in the two lines. There was a 37\% reduction in downtime after the implementation in line 1. The statistical test between the before and after values shows a statistically significant change in line 1 . On line 2 , on average, there was a non-significant increase in the number of downtime hours (29\%), i.e., the machine on line 2 was less available.

\subsection{Relationship between motivation and operational performance}

To analyze the relationship between the motivation factors found and the performance of the two production lines, the information was compiled in Table 3. 
Table 2. Operational performance indicators before and after implementation in lines 1 and 2.

\begin{tabular}{|c|c|c|c|c|c|c|c|c|c|c|}
\hline & \multicolumn{5}{|c|}{6 months before } & \multicolumn{5}{|c|}{6 months after } \\
\hline & $\begin{array}{l}\text { Month/ } \\
\text { year }\end{array}$ & $\begin{array}{c}\text { Total } \\
\text { BRL/1000 u }\end{array}$ & Waste $\%$ & OEE $\%$ & $\begin{array}{c}\text { Downtime } \\
\text { Hours }\end{array}$ & $\begin{array}{l}\text { Month/ } \\
\text { year }\end{array}$ & $\begin{array}{c}\text { Total } \\
\text { BRL/1000 } \\
\mathrm{u}\end{array}$ & Waste $\%$ & OEE $\%$ & $\begin{array}{c}\text { Downtime } \\
\text { Hours }\end{array}$ \\
\hline \multirow{6}{*}{ line 1} & $\mathrm{jul} / 17$ & 163.6 & 3.9 & 64.0 & 132.60 & $\mathrm{fev} / 18$ & 123.6 & 2.3 & 75.7 & 90.20 \\
\hline & ago/17 & 91.4 & 2.6 & 68.5 & 178.30 & $\mathrm{mar} / 18$ & 98.8 & 2.3 & 80.1 & 128.90 \\
\hline & set/17 & 114.9 & 3.2 & 70.9 & 128.50 & $\mathrm{abr} / 18$ & 92.1 & 2.4 & 79.8 & 73.80 \\
\hline & out/17 & 88.8 & 2.6 & 73.1 & 132.40 & mai/18 & 106.8 & 2.1 & 80.5 & 121.80 \\
\hline & nov/17 & 128.0 & 2.6 & 74.0 & 103.10 & jun/18 & 101.0 & 1.9 & 81.7 & 59.80 \\
\hline & $\mathrm{dez} / 17$ & 108.7 & 2.7 & 72.1 & 121.40 & jul/18 & 92.2 & 2.0 & 81.3 & 33.40 \\
\hline Mean & & 115.9 & 2.9 & 70.4 & 132.72 & & 102.4 & 2.2 & 79.9 & 96.45 \\
\hline $\begin{array}{l}\text { Standard } \\
\text { Deviation }\end{array}$ & & 27.6 & 0.5 & 3.7 & 22.73 & & 11.8 & 0.2 & 2.2 & 28.31 \\
\hline $\begin{array}{l}\text { Coefficient of } \\
\text { variation }(\%)\end{array}$ & & 23.8 & 17.2 & 5.3 & 0.17 & & 11.5 & 9.1 & 2.8 & 0.29 \\
\hline Gain (\%) & & & & & & & -13.18 & -31.81 & +11.88 & -37.6 \\
\hline p-value & & & & & & & 0.1562 & 0.0051 & 0.0051 & 0.0455 \\
\hline \multirow{6}{*}{ line 2} & jun/17 & 108.4 & 2.2 & 81.3 & 46.30 & jan/18 & 113.2 & 2.7 & 78.6 & 74.70 \\
\hline & jul/17 & 88.1 & 2.4 & 80.3 & 125.80 & $\mathrm{fev} / 18$ & 101.8 & 2.2 & 80.1 & 138.60 \\
\hline & ago/17 & 101.8 & 3.3 & 75.3 & 75.60 & $\mathrm{mar} / 18$ & 89.2 & 2.0 & 84.4 & 153.30 \\
\hline & set/17 & 100.3 & 2.6 & 76.3 & 116.60 & $\mathrm{abr} / 18$ & 90.3 & 2.4 & 79.7 & 144.00 \\
\hline & out/17 & 89.4 & 2.2 & 82.1 & 93.80 & mai/18 & 94.7 & 2.4 & 80.5 & 100.20 \\
\hline & nov/17 & 121.1 & 2.5 & 79.7 & 120.60 & jun/18 & 101.8 & 2.0 & 84.7 & 109.00 \\
\hline Mean & & 101.5 & 2.5 & 79.2 & 84.65 & & 98.5 & 2.3 & 81.3 & 119.97 \\
\hline $\begin{array}{l}\text { Standard } \\
\text { Deviation }\end{array}$ & & 12.3 & 0.4 & 2.7 & 33.49 & & 9.0 & 0.3 & 2.6 & 27.68 \\
\hline $\begin{array}{l}\text { Coefficient of } \\
\text { variation }(\%)\end{array}$ & & 12.1 & 16 & 3.4 & 0.40 & & 9.1 & 13.0 & 3.2 & 0.23 \\
\hline Gain (\%) & & & & & & & -3.04 & -8.69 & +2.58 & +29.44 \\
\hline$p$-value & & & & & & & 0.0625 & 0.2983 & 0.4237 & 0.2983 \\
\hline
\end{tabular}

Table 3. Relationship between Motivation factor and variation in Operational Performance.

\begin{tabular}{|c|c|c|c|c|}
\hline Machines & Motivation factor & $\begin{array}{l}\Delta \mathrm{x} \text { Product Cost Post- } \\
\text { Implementation }\end{array}$ & $\begin{array}{l}\Delta \mathrm{x} \text { Waste Post- } \\
\text { Implementation }\end{array}$ & $\begin{array}{l}\Delta x \text { Productivity Post- } \\
\text { Implementation }\end{array}$ \\
\hline Line 1 & 202 & $-13.18 \%$ & $-31.81 \%$ & $+11.88 \%$ \\
\hline line 2 & 105 & $-3.04 \%$ & $-8.69 \%$ & $+2.58 \%$ \\
\hline
\end{tabular}

Source: Authors.

The data in this table were used to construct a graph (figure 2) with two axes, where the motivation factor is represented in the main axis (columns) and the operational results (gains) in the secondary axis (points connected by a line).

In Figure 2, the lowest mean Motivation factor is found in line 2, where there was a 3\% reduction in the mean cost product after implementation. In line 1, there was a 13\% reduction in the mean product cost, so it is observed that the line that had the highest mean Motivational Factor was also the one with the greatest reduction in product cost.

Regarding the waste performance indicator, the results are similar to the previous relationship: line 2 obtained a smaller reduction in the mean percentage waste of $-8.69 \%$, while line 1 had a reduction of $-31.81 \%$ in the mean percentage waste.

In the third relationship, it is observed that line 2 , as in the previous analyses, had a smaller increase in percentage efficiency with only $2.58 \%$, and line 2 showed an $11.88 \%$ increase in efficiency. .

\section{Discussion}

After analyzing the results, it can be concluded that line 1 showed a significant evolution after the implementation of the TPM, supporting hypothesis 2 , which advocated a positive impact after implementation of TPM. Although line 2 showed improvements (with the exception of the mean downtime, which increased), 


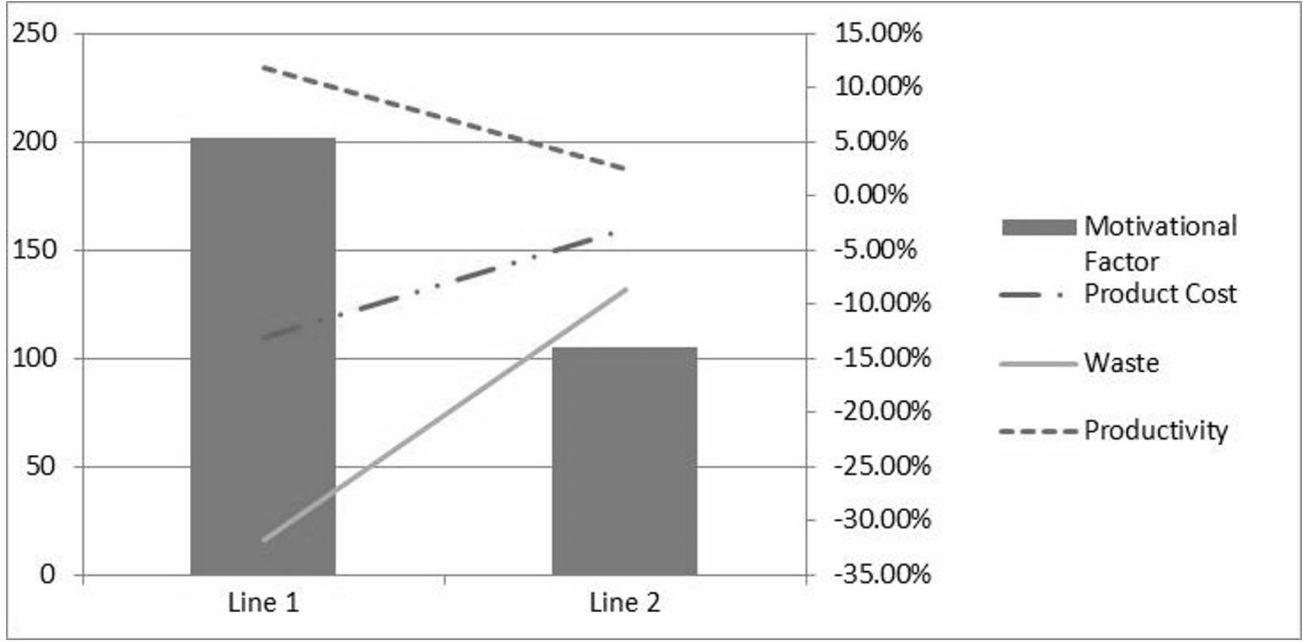

Figure 2. Relationship between Motivation factor and variation in Operational performance indicators. Source: Authors.

the variations were smaller and not statistically significant. The three relationships between motivation and operational performance support hypothesis 1, referring to the positive relationship between the level of motivation of the team and changes in operational performance after implementation. When there is a greater Motivation factor, there is also a lower cost product, a smaller waste in the process and greater efficiency, which is the case of line 1. These results between motivation and performance corroborate the predictions and assumptions of Vroom's Expectancy Theory (Vroom, 1964). During the implementation, some meetings and unstructured interviews were conducted with the operational team, with all operators and in some cases only with the chief operators of the two lines. Despite having shown a slight evolution, during these meetings, it was possible to observe that there was a great difficulty in taking over the activities when the shift changed (where the rotation of the teams occurred) in the line 2 team. Often the team taking over the shift ended up having to redo many of the activities that had already been performed by the previous team, demonstrating misalignment and/or lack of information regarding the direction and/or execution of the activities performed. This perception is evident in the following quotes:

[...] We have communication problems in the Line 2 team. When the shift changes, many activities such as configurations and setups are done but are not actually necessary, since the workers in the previous shift have already performed them [...] this creates a bad atmosphere among teams. Teams from previous shifts are blamed for making the teams from subsequent shifts waste time (Chief Operator, line 2).

Another aspect that should be emphasized is that it was possible to perceive, through the unstructured interviews, that the line 2 team had a relatively good relationship, but there was still a lack of confidence in the reason for the execution or nonexecution of some specific activities that apparently were the responsibility of another shift. In addition, the team did not have the openness to provide constructive criticism of the work of peers, even if this could impact the result. At many times, there were complaints about the direction and activities performed by the other shifts. There was a situation where the first shift believed that only they performed the activities and that the third shift did everything possible to not have to solve the problems, leaving them for the first shift to solve; and the second shift had the impression that the first shift did not solve the problems or did not perform the machine downtime activities so they had to stop the machine and solve the problems. In addition, the third shift had the impression that they should not perform machine downtime activities because the other shifts had "more support", i.e., all of the shifts in line 2 felt that there was a lack of commitment to the activities by the teams of the other shifts. This created a certain discomfort and dissatisfaction among line 2 employees and hindered the execution of the activities, as some employees delayed the machine downtime, even when there were problems. All this corroborates the results obtained on the motivation factor in the lines. These problems can be illustrated by following quotes from a line 2 employee who works on the first shift:

[...] When we initiate our (first) shift, we often have to do activities that, we believe, should be performed by the previous team. We criticized them to the support team, but nothing was solved. We lose a lot of time doing these activities ourselves [...] we believe that some of the problems that are found, originate during previous shifts, and it is their responsibility to fix them. (Operator, Line 2). 
Regarding the performance of line 2, it was evident during the analyzed months that the line 2 team struggled to deliver the result on a daily basis, but some factors also decreased the motivation of the team. For example, in the unstructured interviews, it was pointed out that any unexpected changes in production planning, immediate changes in the production sequence requested by the sales team - which generated machine downtime and, in most cases, equipment setup problems - caused the operators to lose focus on the setup activity, generating deep demotivation, and negatively impacting the efficiency of the equipment after setup. The following quote can illustrate the situation:

[...] we face changes in the production plan and these changes impact the downtime of the machine and the performance of our Line. Setup becomes difficult [...] this sense of instability is not good for us, and we feel frustrated with all these changes, which make us more dependent on our supervisor and on the support people (Operator, Line 2).

As it was demonstrated, the observations and unstructured interviews with the line 2 team revealed that the group showed emotional exhaustion and concern about not achieving the expected results. Vroom (1964) mentions that if the individual perceives that, even when expending a great effort, the result obtained does not change significantly, he or she will tend not to exert much effort. This proposition seems to underlie the demotivation behavior of Line 2 members. The unstructured interviews, exemplified above, also revealed that the Line 2 team did not make important decisions regarding the process and that they depended on an outsider, from the support team, in most situations, to decide what it was necessary to do and who should do it.

The growing field of behavioral operations management aims to improve and make better use of operations practice and theories, so that recent findings in behavioral sciences bring benefits and potential improvements to operations approaches (Donohue et al., 2020).

The results presented here confirm and reinforce the findings, found in the literature, which establish a relation between the level of employee motivation during TPM implementation and results in terms of operational performance (Jain et al., 2018; Kareem \& Amin, 2017; Bamber et al., 1999; Attri et al., 2013; Sharma et al., 2016). The relation between motivation and performance has been studied in other contexts related to manufacturing, with similar results. The findings presented here are supported by these other authors, such as Abreu (2011), Bennett \& Levinthal (2017), Cordero et al. (2005), DiPietro et al. (2014), Dogra et al. (2011), Guclu \& Guney (2017), Guo et al. (2017), Khan \& Baloch (2017), Ljungberg (1998), Mckone et al. (2001), Sekhar et al. (2013) and Tondato (2004), adding evidence to the field of research that associates human factors with performance in production.

These results also corroborate Marks et al. (2001), who state that even if a team achieves good production rates, if its members are not satisfied and motivated by the work, and if they do not have good social relations with each other, it is not appropriate to consider it effective. According to the authors, a team's success comes from motivation and good social relations, and neglecting these two conditions would compromise its functioning. They also corroborate the statement by Martins et al. (2017) that the motivational cycle begins with a push for performance, creating an imbalance.

In addition, the positive and significant results obtained with the TPM implementation in line 1 add evidence to the literature focused on its benefits (Hooi \& Leong, 2017; Modgil \& Sharma, 2016; Habidin et al., 2018; Wickramasinghe \& Perera, 2016). The fact that line 2 showed mostly modest and statistically non-significant improvements can be taken as a cautionary lesson; the mere implementation of TPM does not ensure success, and human factors should not be overlooked. Managers must, therefore, pay attention to the factors that determine the motivation of work teams when implementing improvement programs, such as TPM (Jahn, 1996; Nesan \& Holt, 1999; DiPietro et al., 2014).

\section{Conclusion}

This study analyzed the role of the motivation of the teams of two production lines of an industrial company in the operational performance obtained with the implementation of TPM. Evidence was found of the impact of the TPM program on operational performance. Among the research hypotheses, there is evidence supporting the hypotheses (in this case study): $\mathrm{H} 1$ : A higher level of motivation is associated with a positive change in operational performance; and H2: The implementation of the TPM program has a positive effect on operational performance. Thus, it is important that companies have working practices and conditions that foster the motivation of their employees, and such practices were identified in the literature review. As was previously explained, the focus of this study is on the role of motivation in the implementation process, and not on the day-to-day operations of companies using TPM. This constitutes an additional contribution of the research.

The major contribution of this study is therefore to combine human behavior with operations issues, in line with the growing importance of the human factor in current studies in the field of operations, which demonstrates 
the importance of people management. The behavior of workers and teams is necessary to inform adjustments or abandonment of pre-existing practices, creation of new practices, and especially the monitoring of management practices and their results according to the realities specific to each production site. The main limitation of this study is the low external validity, as it is a case study that cannot be generalized. Future quantitative studies with a survey design, collecting data from several companies, and using normalized and control variables, are necessary for increasing the external validity of the evidence shown here. In addition, the periods of analysis (of data collection and interval between them) should have been longer. However, this was not possible because of the recency of the changes and due to limitations of the study design itself. The fact that team motivation was measured only at one moment in time, i.e., after the implementation of TPM, is another limitation.

\section{References}

Abreu, V. D. F. (2011). A influência da motivação na produtividade do posto de trabalho: Aplicação à indústria automóvel. (Dissertação de mestrado). Instituto Politécnico de Viseu, Portugal.

Alves, R., Costa, D. V. F., Ferreira, V. C. P., Costa, M. P. C., \& Ferreira, E. V. (2016). 0 Desafio de Administrar a Motivação: Um estudo em uma rede supermercadista. Revista da Faculdade de Administração e Economia, 7(2), 73-97. http://dx.doi.org/10.15603/21769583/refae.v7n2p73-97.

Alves Filho, A., \& Borges, L. O. (2014). A motivação dos profissionais de saúde das unidades básicas de saúde. Psicologia (Conselho Federal de Psicologia), 34(4), 984-1001. http://dx.doi.org/10.1590/1982-370001082013.

Attri, R., Grover, S., Dev, N., \& Kumar, D. (2013). An ISM approach for modelling the enablers in the implementation of Total Productive Maintenance (TPM). International Journal of System Assurance Engineering and Management, 4(4), 313-326. http://dx.doi. org/10.1007/s13198-012-0088-7.

Bamber, C. J., Sharp, J. M., \& Hides, M. T. (1999). Factors affecting successful implementation of total productive maintenance: a UK manufacturing case study perspective. Journal of Quality in Maintenance Engineering, 5(3), 162-181. http://dx.doi. org/10.1108/13552519910282601.

Bennett, V. M., \& Levinthal, D. A. (2017). Firm lifecycles: Linking employee incentives and firm growth dynamics. Strategic Management Journal, 38(10), 2005-2018. http://dx.doi.org/10.1002/smj.2644.

Boer, H., \& Gertsen, F. (2003). From continuous improvement to continuous innovation: a (retro)(per)spective. International Journal of Technology Management, 26(8), 805-827. http://dx.doi.org/10.1504/1JTM.2003.003391.

Borges, L. D. 0., \& Alves Filho, A. (2001). A mensuração da motivação e do significado do trabalho. Estudos de Psicologia, 6(2), 177194. http://dx.doi.org/10.1590/S1413-294X2001000200006.

Borges, L. D. O., \& Alves Filho, A. (2003). A estrutura fatorial do Inventário do Significado e Motivação do Trabalho, IMST. Avaliação Psicológica, 2(2), 123-145.

Borges, L. O., Alves Filho, A., \& Tamayo, A. (2008). Motivação e significado do trabalho. In M. M. M. Siqueira et al. (Eds), Medidas do comportamento organizacional: Ferramentas de diagnóstico e de gestão (pp.215-248). Porto Alegre: Artmed.

Campbell, J. J., Dunnette, M. D., Lawler, E. E., Weick, K. E. (1970). Managerial behavior, performance, and effectiveness. New York: McGraw-Hill Book Company.

Cordero, R., Walsh, S. T., \& Kirchhoff, B. A. (2005). Motivating performance in innovative manufacturing plants. The Journal of High Technology Management Research, 16(1), 89-99. http://dx.doi.org/10.1016/j.hitech.2005.06.005.

Di Cesare, J., \& Sadri, G. (2003). Do all carrots look the same? Examining the impact of culture on employee motivation. Management Research News, 26(1), 29-40. http://dx.doi.org/10.1108/01409170310783394.

DiPietro, R. B., Kline, S. F., \& Nierop, T. (2014). Motivation and satisfaction of lodging employees: An exploratory study of Aruba. Journal of Human Resources in Hospitality \& Tourism, 13(3), 253-276. http://dx.doi.org/10.1080/15332845.2014.866466.

Dogra, M., Sharma, V., Sachdeva, A., \& Dureja, J. (2011). TPM - a key strategy for productivity improvement in process industry. Journal of Engineering Science and Technology, 6(1), 1-16.

Donohue, K., Özer, Ö., \& Zheng, Y. (2020). Behavioral operations: Past, present, and future. Manufacturing \& Service Operations Management : M\& SOM, 22(1), 191-202. http://dx.doi.org/10.1287/msom.2019.0828.

Erez, M. (1997). A culture based model of work motivation. In P. C. Earley, \& M. Erez (Eds.), New Perspectives on International Industrial/ Organizational Psychology (pp. 193-242). San Francisco, CA: Jossey-Bass.

Frohman, M. A. (1996). Unleash urgency and action. Industry Week, 245(20), 13-23.

Gagné, M., Forest, J., Gilbert, M.-H., Aubé, C., Morin, E., \& Malorni, A. (2010). The Motivation at Work Scale: Validation evidence in two languages. Educational and Psychological Measurement, 70(4), 628-646. http://dx.doi.org/10.1177/0013164409355698.

Gaiardelli, P., Resta, B., \& Dotti, S. (2019). Exploring the role of human factor in Lean Management. International Journal of Lean Six Sigma, 10(1), 339-366. http://dx.doi.org/10.1108/1JLSS-08-2017-0094.

Guclu, H., \& Guney, S. (2017). The effect of the motivation techniques used by managers to increase the productivity of their workers and an application. Business Management Dynamics, 6(7), 1-18.

Guo, L., Tobias, J., Bendoly, E., \& Hu, Y. (2017). Different departments, different drivers: Asymmetry in antecedents and outcomes of voluntary knowledge exchange between sales and production functions. International Journal of Operations \& Production Management, 37(8), 1031-1053. http://dx.doi.org/10.1108/1JOPM-01-2016-0046.

Habidin, N. F., Hashim, S., Fuzi, N. M., \& Salleh, M. 1. (2018). Total productive maintenance, kaizen event, and performance. International Journal of Quality \& Reliability Management, 35(9), 1853-1867. http://dx.doi.org/10.1108/lJQRM-11-2017-0234.

Hansen, R. C. (2005). Overall equipment effectiveness: A powerful production/maintenance tool for increased profits. Norwalk: Industrial Press. 
Herzberg, F. (2008). One more time: How do you motivate employees? Boston: Harvard Business Review Press.

Hooi, L. W., \& Leong, T. Y. (2017). Total productive maintenance and manufacturing performance improvement. Journal of Quality in Maintenance Engineering, 23(1), 2-21. http://dx.doi.org/10.1108/JQME-07-2015-0033.

Imai, Y. (2000). TPM como estratégia empresarial. São Paulo: IMC Internacional.

Jahn, B. (1996). McGraw-hill's best practices for housing construction. São Paulo: McGraw Hill.

Jain, A., Singh, H., \& Bhatti, R. S. (2018). Identification of key enablers for total productive maintenance (TPM) implementation in Indian SMEs: A graph theoretic approach. Benchmarking, 25(8), 2611-2634. http://dx.doi.org/10.1108/BlJ-02-2016-0019.

Kanfer, R., Frese, M., \& Johnson, R. E. (2017). Motivation related to work: A century of progress. The Journal of Applied Psychology, 102(3), 338-355. http://dx.doi.org/10.1037/apl0000133. PMid:28150980.

Kareem, J. A. H., \& Amin, O. A. Q. H. (2017). Ethical and psychological factors in 5 S and total productive maintenance. Journal of Industrial Engineering and Management, 10(3), 444-475. http://dx.doi.org/10.3926/jiem.2313.

Khan, 1., \& Baloch, Q. B. (2017). Performance based pay: A moderator of relationship between employee workplace behavior and organization productivity. Journal of Managerial Sciences, 11(1), 39-50.

Lee Cooke, F. (2000). Implementing TPM in plant maintenance: Some organizational barriers. International Journal of Quality \& Reliability Management, 17(9), 1003-1016. http://dx.doi.org/10.1108/02656710010378789.

Ljungberg, O. (1998). Measurement of overall equipment effectiveness as a basis for TPM activities. International Journal of Operations \& Production Management, 18(5), 495-507. http://dx.doi.org/10.1108/01443579810206334.

Macintosh, E. W., \& Doherty, A. (2010). The influence of organizational culture on job satisfaction and intention to leave. Sport Management Review, 13(2), 106-117. http://dx.doi.org/10.1016/j.smr.2009.04.006.

Madu, C. (2000). Competing through maintenance strategies. International Journal of Quality \& Reliability Management, 1799), 937948. http://dx.doi.org/10.1108/02656710010378752.

Marks, M. A., Mathieu, J. E., \& Zaccaro, S. J. (2001). A temporal based framework and taxonomy of team processes. Academy of Management Review, 26(3), 356-376. http://dx.doi.org/10.5465/amr.2001.4845785.

Martins, C. S., Ribeiro, M. E. 0., Antoniolli, B. 1., \& Silva, J. M. S. (2017). Fatores Motivacionais que influenciam no desempenho dos colaboradores no Ambiente de Trabalho. Id on Line Revista Multidisciplinar e de Psicologia, 12(39), 262-281. http://dx.doi. org/10.14295/idonline.v12i39.989.

Maurer, T. J., \& Tarulli, B. A. (1994). Investigation of perceived environment, perceived outcome, and person variables in relationship to voluntary development activity by employees. The Journal of Applied Psychology, 79(1), 3-14. http://dx.doi.org/10.1037/00219010.79.1.3. PMid:8200872.

Michela, J. L., Noori, H., \& Jha, S. (1996). The dynamics of continuous improvement. International Journal of Quality Science, 1(1), 19-47. http://dx.doi.org/10.1108/13598539610117975.

Mckone, K. E., Schroeder, R. G., \& Cua, K. O. (2001). The impact of total productive maintenance practices on manufacturing performance. Journal of Operations Management, 19(1), 39-58. http://dx.doi.org/10.1016/S0272-6963(00)00030-9.

Meselhy, K. T., Elmaraghy, W. H., \& Elmaraghy, H. A. (2010). A periodicity metric for assessing maintenance strategies. CIRP Journal of Manufacturing Science and Technology, 3(2), 135-141. http://dx.doi.org/10.1016/j.cirpj.2010.06.004.

Modgil, S., \& Sharma, S. (2016). Total productive maintenance, total quality management and operational performance. Journal of Quality in Maintenance Engineering, 22(4), 353-377. http://dx.doi.org/10.1108/JQME-10-2015-0048.

Muchiri, P., Pintelon, L., Gelders, L., \& Martin, H. (2011). Development of maintenance function performance measurement framework and indicators. International Journal of Production Economics, 137(1), 295-302. http://dx.doi.org/10.1016/j.ijpe.2010.04.039.

Nakajima, S. (1998). Introduction to Total Productive Maintenance (TPM). Cambridge: Productivity Press.

Nakazato, K. (1999). Manual de implementação do TPM. Japão: Japan Institute of Plant Maintenance.

Nesan, L. J., \& Holt, G. D. (1999). Empowerment in construction: The way forward for performance improvement. Baldock, Hertfordshire, England: Research Studies Press.

Noe, R. A., \& Wilk, S. L. (1993). Investigation of the factors that influence employees' participation in development activities. The Journal of Applied Psychology, 78(2), 291-302. http://dx.doi.org/10.1037/0021-9010.78.2.291.

Papke-Shields, K. E., Beise, C., \& Quan, J. (2010). Do project managers practice what they preach, and does it matter to project success? International Journal of Project Management, 28(7), 650-662. http://dx.doi.org/10.1016/j.jproman.2009.11.002.

Petter, R. R., Vaz, C. R., Resende, L. M. M., \& Selig, P. M. (2011). Produção limpa, produção mais limpa, produção enxuta, 5s e manutenção autônoma: uma proposta metodológica de implantação conjunta. In Anais do VII Congresso Nacional de Excelência em Gestão (pp. 1-23). Rio de Janeiro: UFF.

Pintelon, L., \& Van Puyvelde, F. (2006). Maintenance decision making. Leuven, Belgium: Acco.

Ruffatto, J., Pauli, J., \& Rafael Ferrão, A. (2017). Influência do estilo de liderança na motivação e conflitos interpessoais em empresas familiares. Revista de Administração FACES Journal, 16(1), 29-44. http://dx.doi.org/10.21714/1984-6975FACES2017V16N1ART3616.

Sekhar, C., Patwardhan, M., \& Singh, R. K. (2013). A literature review on motivation. Global Business Perspectives, 1(4), 471-487. http:// dx.doi.org/10.1007/s40196-013-0028-1.

Sellitto, M. A., Borchardt, M., \& Araújo, D. R. C. (2002). Manutenção centrada em confiabilidade: aplicando uma abordagem quantitativa. Anais do XXII Encontro Nacional de Engenharia de Produção (pp.1-8). Curitiba: ABEPRO.

Sharma, R., Singh, J., \& Rastogi, V. (2016). Importance and effectiveness of human related issues in implementing total productive maintenance: a study of Indian manufacturing organisations. International Journal of Industrial and Systems Engineering, 23(4), 420-434. http://dx.doi.org/10.1504/IJISE.2016.077694.

Silva, N. I. A. (2009). Conflitos intragrupos: Preditores e consequentes no cenário de equipes de trabalho (Dissertação de mestrado). Universidade de Brasília, Brasília. 
Silva, A. V., \& Barros, F. C. (2018). Motivação no trabalho dos servidores técnicos administrativos em educação. Revista Eletrônica Gestão e Serviços, 9(2), 2473-2495. http://dx.doi.org/10.15603/2177-7284/regs.v9n2p2473-2495.

Stringer, C., Didham, J., \& Theivananthampillai, P. (2011). Motivation, pay satisfaction, and job satisfaction of front-line employees. Qualitative Research in Accounting \& Management, 8(2), 161-179. http://dx.doi.org/10.1108/11766091111137564.

Taherdoost, H., \& Keshavarzsaleh, A. (2016). Critical factors that lead to projects' success/failure in global marketplace. Procedia Technology, 22, 1066-1075. http://dx.doi.org/10.1016/j.protcy.2016.01.151.

Takahashi, Y., \& Osada, T. (1993). TPM/MPT: Manutenção produtiva total. São Paulo: IMAM.

Tondato, R. (2004) Manutenção produtiva total: Estudo de caso na indústria gráfica. (Dissertação de mestrado). Universidade Federal do Rio Grande do Sul, Porto Alegre.

Varella, J. M. C. (2006). A motivação e o significado do trabalho de bancários: estudo comparativo entre dois momentos do processo de reestruturação produtiva. (Dissertação de mestrado). Universidade Federal do Rio Grande do Norte, Natal.

Venkatesh, J. (2003). Introduction to total productive maintenance (TPM). The Plant Maintenance Resource Center.

Vroom, V. H. (1964). Work and motivation. Nova York: John Wiley \& Sons.

Wickramasinghe, G. L. D., \& Perera, A. (2016). Effect of total productive maintenance practices on manufacturing performance: Investigation of textile and apparel manufacturing firms. Journal of Manufacturing Technology Management, 27(5), 713-729. http://dx.doi.org/10.1108/JMTM-09-2015-0074.

Wienclaw, R. A. (2018). Operations and business process management. Retrieved in 10 June 2020, from http://connection.ebscohost. com/c/essays/27577979/operations-business-process-management.

Wilcoxon, F. (1945). Individual comparisons by ranking methods. Biometrics Bulletin, 1(6), 80-83. http://dx.doi.org/10.2307/3001968. 